\title{
ЕМПАТІЯ У СФЕРІ МЕДИЧНОЇ ОСВІТИ - ДІАГНОСТИЧНІ ІНСТРУМЕНТИ
}

I. В. Гусакова

\author{
Вінницький національний медичний університет імені М. І. Пирогова
}

\section{EMPATHY IN THE SPHERE OF MEDICAL EDUCATION - DIAGNOSTIC INSTRUMENTS}

\section{V. Husakova}

\author{
Vinnytsia National Medical University by M. I. Pyrohov
}

\begin{abstract}
У статті подається інформація щодо сучасних методів діагностики емпатії у працівників медичної сфери та студентівмедиків, аналізуються та порівнюються психометричні дані та діагностичні можливості тестів діагностики емпатії, зазначається необхідність адаптації деяких спеціалізованих іншомовних методик для вітчизняних студентів-медиків та лікарів.
\end{abstract}

The information about modern methods of empathy diagnostics in the specialists of medical sphere and medical students is presented in this article, the psychometric data and diagnostic possibilities of empathy tests are analyzed and compared, the necessity of adaptation of some specialized foreign language diagnostic instruments for Ukrainian medical students and physicians is pointed out.

Вступ. Термін “емпатія” уведений у психологію Е. Титченером і активно використовується з початку XX сторіччя. Під емпатією (від грец. еmpatheia співчуття) розуміють здатність людини відчувати та аналізувати емоційний стан інших людей. У філософії емпатія - це пізнання внутрішнього світу іншого індивіда, а також чуттєво-емоційне реагування суб'єкта на негативні та позитивні почуття - емоції іншого суб'єкта у формі співчуття, солідарності тощо [1]. У психології розрізняють декілька підходів до розуміння емпатії:

1 - емпатія як психічний процес;

2 - емпатія як психічна реакція у відповідь на діючий стимул;

3 - емпатія як властивість особистості [2].

У сучасній психології переважно реалізується інтегративний підхід до розуміння емпатії як складного соціально-психологічного феномену, причому формування емпатії пов' язується із процесом соціалізації. До факторів, що мають безпосередній вплив на формування емпатії, відносять особливості виховання, індивідуальний досвід спілкування, особливості міжособистісних відносин.

У медицині термін “емпатія” має дещо інший відтінок: “клінічну емпатію” визначають як адекватне розуміння внутрішніх психічних процесів паці- єнта стосовно його проблем зі здоров'ям [3]. K. A. Stepien та A. Baernstein характеризують клінічну емпатію не лише як розуміння емоцій пацієнта, але i як реалізацію проявів цього розуміння по відношенню до пацієнта [4]. На думку S. W. Mercera [5], клінічна емпатія включає в себе:

1 - здатність зрозуміти стан пацієнта, його почуття (емоції);

2 - здатність спілкуватись 3 пацієнтом 3 метою розуміння його психічного стану, його емоцій та перевірки точності цього розуміння;

3 - здатність діяти певним терапевтичним шляхом (з урахуванням розуміння психічного стану пацієнта).

Іноді емпатію називають "humanism at heart" - гуманізмом в серці [6].

У широкому розумінні термін "клінічна емпатія" об'єднує 4 атрибути (4 компоненти емпатіі): когнітивний, емоційний, поведінковий та мотиваційний [7]. Когнітивна емпатія (усвідомлення та розуміння емоцій та почуттів іншої людини) реалізується шляхом інтенсивної аналітичної обробки інформації стосовно психічних процесів пацієнта. Емоційна емпатія $\epsilon$ вікарною (замісною) емоційною реакцією лікаря на почуття іншої людини, яка відображає емоції даної людини або є співзвучною їй (співчуття, співпережи-

(C) I. В. Гусакова 
вання). Емоційна емпатія реалізується за посередництвом емоційного досвіду. Поведінкова емпатія розцінюється як вольова співучасть, коли лікар безпосередньо бере участь в емотивних взаємовідносинах, спрямовуючи їх у певне русло і коригуючи емоційні реакції пацієнта. Мотиваційний компонент емпатії спонукає лікаря до надання адекватної допомоги пацієнту 3 метою відновлення у нього стану фізичного та психологічного комфорту.

Будь-яке спілкування між лікарем і пацієнтом приводить до виникнення емпатичних взаємовідносин і формування емпатичної відповіді. Вважають, що формування емпатичної відповіді $є$ мультифазним процесом, який включає в себе внутрішню резонансну фазу, комунікативну фазу та рецептивну фазу [8].

Емпатія $є$ надзвичайно важливим компонентом професійної діяльності працівників медичної сфери. Іїі вважають одним з елементів професіоналізму лікаря [9].

Основна частина. Метою даної роботи $є$ аналіз сучасних можливостей діагностики емпатії у сфері медичної освіти та практичної охорони здоров'я.

Варто зазначити, що для діагностики емпатії застосовують численні методики [10]. J. М. Hemmerdinger, S. D. Stoddart, R. J. Lilford [11] нарахували 36 різних інструментів діагностики емпатії в медицині. Найчастіше для діагностики емпатії використовують кількісні методики, тоді як якісні підходи в медицині застосо- вують, на жаль, рідко. Усі діагностичні методики можуть бути розділені на три групи:

- тести самооцінки - оцінка емпатії за допомогою стандартизованих опитувальників, які дозволяють протестувати різні аспекти власної поведінки та емоцій у контексті взаємовідносин з пацієнтами;

- пацієнтооціночні тести - оцінка емпатії медичного працівника за допомогою спеціальних опитувальників, відповіді на питання яких дають пацієнти;

- тести спостереження - використання стандартизованих методик, у процесі проведення яких спостерігач фіксує емпатичні прояви під час контакту медичних працівників і пацієнтів (включаючи “стандартизованих" пацієнтів або симулюючих пацієнтів).

Зрозуміло, що тести другого та третього типів не можуть використовуватися як скринінгові методики у студентів-медиків.

Серед тестів першої групи найуживанішими $є$ Jefferson Scale of Physician Empathy (JSPE - два варіанти: Student or S Version та Health Professional or HP Version), Balanced Emotional Empathy Scale (BEES), Empathy Test (ET), Davis' Interpersonal Reactivity Index (DIRI or IRI), Empathy Construct Rating Scale (ECRS), Empathy, Spirituality, and Wellness in Medicine survey (ESWIM).

У таблиці 1 наведені психометричні дані щодо надійності, внутрішньої узгодженості та валідності зазначених діагностичних методик.

Таблиця 1. Методики діагностики емпатії (надійність, внутрішня узгодженість та валідність)

\begin{tabular}{|c|c|c|c|c|}
\hline Тест & Тип тесту & Надійність & Внутрішня узгодженість & Валідність \\
\hline $\begin{array}{c}\text { Jefferson Scale of } \\
\text { Physician Empathy } \\
\text { (JSPE) }\end{array}$ & 1-го типу & $\begin{array}{c}\text { Тест-ретест кореляція } \\
(\mathrm{r}=0,65), \text { показник Кохена } \\
(\mathrm{d}=0,29, \mathrm{p}<0,05)\end{array}$ & $\begin{array}{c}\text { Показник Кросбаха } \\
\text { (Crosbach’s alpha=0,81-0,89) }\end{array}$ & $\begin{array}{l}\text { Методика } \\
\text { валідна }\end{array}$ \\
\hline $\begin{array}{c}\text { Balanced Emotional } \\
\text { Empathy Scale (BEES) }\end{array}$ & $1-\Gamma$ & $\begin{array}{c}\text { Тест-ретест зміни } \\
\text { (Wilcoxon } \mathrm{z}=-0,254, \mathrm{p}<0,01)\end{array}$ & $\begin{array}{r}\text { Показник Кр } \\
\text { (Crosbach's alp }\end{array}$ & $\begin{array}{c}\text { Методика } \\
\text { валідна }\end{array}$ \\
\hline Empathy Test (ET) & $1-\Gamma \mathrm{C}$ & $\begin{array}{c}\text { Тест-ретест кореляція } \\
(\mathrm{r}=0,37)\end{array}$ & $\begin{array}{c}\text { Показник Кросбаха } \\
\text { (Crosbach's alpha=0,18-0,42) }\end{array}$ & $\begin{array}{c}\text { Методика } \\
\text { валідна }\end{array}$ \\
\hline $\begin{array}{c}\text { Davis' Interpersonal } \\
\text { Reactivity Index (DIRI) }\end{array}$ & $1-\Gamma$ & $\begin{array}{c}\text { Статистично вірогідні } \\
\text { зміни протягом 3-х років } \\
\text { (effective size }=-0,51, \mathrm{p}=0,05 \text { ) }\end{array}$ & $\begin{array}{c}\text { Показник Кросбаха } \\
\text { (Crosbach's alpha=0,72-0,77) }\end{array}$ & $\begin{array}{l}\text { Методика } \\
\text { валідна }\end{array}$ \\
\hline $\begin{array}{c}\text { Empathy Construct Rating } \\
\text { Scale (ECRS) }\end{array}$ & 1-го типу & $\begin{array}{c}\text { Тест-ретест зміни } \\
\text { (Wilcoxon } z=-1,10, p=0,27 \text { ) }\end{array}$ & $\begin{array}{c}\text { Показник Кросбаха } \\
\text { (Crosbach's alpha=0,84) }\end{array}$ & $\begin{array}{c}\text { Методика } \\
\text { валідна }\end{array}$ \\
\hline
\end{tabular}

Проте варто зазначити, що спеціалізованими тестовими методиками, створеними саме для працівників медичної сфери та студентів-медиків, є лише Jefferson Scale of Physician Empathy (JSPE: Student and Health Professional Versions) ta Empathy, Spirituality, and Wellness in Medicine survey (ESWIM).

Jefferson Scale of Physician Empathy являє собою 20-пунктовий опитувальник з варіантами відповіді від 1 до 7 балів на кожне питання (1 бал - повністю не- згодний, 7 балів - повністю згодний). Частина питань JSPE має зворотну розбаловку. Методика запропонована американськими психологами з Jefferson Medical College [12].

Empathy, Spirituality, and Wellness in Medicine survey (ESWIM) - це 44-пунктовий самоопитувальник 3 5-ма варіантами відповідей на кожне питання. Методика запропонована L. F. DiLalla, S. K. Hull, J. K. Dorsey [13]. Однак варто зазначи- 
ти, що дана діагностична методика не вважається валідною [4].

Інші вищенаведені методики діагностики емпатії 1 -го типу не є спеціалізованими для сфери медичної освіти та охорони здоров'я, хоча і досить широко використовуються для оцінки емпатії у студентів-медиків та, рідше, медичних працівників.

Тестовою методикою 2-го типу є Consultation and Relational Empathy (CARE). Дана методика запропонована для обстеження середніх медичних працівників (зокрема медичних сестер) і здійснюється за результатами відповідей пацієнтів. Методика вважається надійною (тест-ретест кореляція (Spearman's rho=0,572, p <0,0001)), валідною, показник Кросбаха (Crosbach's alpha) становить 0,93.

До тестів третього типу належать History-taking Rating Scale (HRS) тa Four Habits Coding Scheme (FHCS).

Методика Four Habits Coding Scheme (FHCS) використовується нечасто, іiі надійність досить висока (inter-rater reliability $=0,72$ ), показник Кросбаха (Crosbach's alpha) дорівнює 0,81, однак кореляція 3 оцінками пацієнтів досить слабка [14].

History-taking Rating Scale (HRS) також є тестом третього типу (оцінка емпатії здійснюється тренованим спостерігачем відповідно до завдань 16-пунктової шкали (оцінка від 1 до 4 балів за пункт згідно 3 специфічними критеріями)) [15]. Методика валідна, спеціалізована для медичних працівників.

У країнах СНД для діагностики емпатії найчастіше використовують самооціночні методики: опитувальник “Діагностика рівня полікомунікативної емпатії за І. М. Юсуповим”, методику В. В. Бойка “Ступінь прояву емпатичних здібностей” та опитувальник А. Меграбяна і Н. Епштейна. Перша методика дозволяє оцінити емпатію за 6 шкалами (емпатія з батьками, тваринами, дітьми, людьми похилого віку, незнайомими людьми та героями художніх

\section{Лiтература}

1. Новейший философский словарь. - [3-е изд., испр.]. Минск : Книжный дом, 2003.-1280 с.

2. Психология общения. Энциклопедический словарь / под общ. ред. А. А. Бодалева. - М. : Изд-во “Когито-центр”, 2011.-512 c.

3. Gelhaus P. The desired moral attitude of the physician: (I) empathy / P. Gelhaus // Med. Health. Care Philos. - 2012. № 15(2). - P. 103-113.

4. Stepien K. A. Education for empathy. A review / K. A. Stepien, A. Baernstein // J. Gen. Intern. Med. - 2006. № 21 (5). - P. 524-530. творів), а також загальний рівень емпатії. Методика В. В. Бойка оцінює раціональний, емоційний, інтуїтивний канали емпатії, а також ідентифікацію в емпатії, проникаючу здатність до емпатії та настанови, що сприяють емпатії. Опитувальник А. Меграбяна та Н. Епштейна включає в себе 25 тверджень, ступінь згоди з якими обстежуваний має оцінити відповіддю вартістю від 1 до 4 балів. Зазначені методики досить часто використовуються у практичній психодіагностиці, проте дані стосовно їх валідності, надійності та внутрішньої узгодженості фрагментарні і досить неоднозначні. Зазначені методики діагностики емпатії на $є$ адаптованими для сфери медичної освіти та практичної охорони здоров’ я. Спеціальної методики, яка б оцінювала емпатію у студентів-медиків та лікарів, у країнах СНД немає.

Висновки. Підсумовуючи результати аналізу останніх публікацій з питання діагностики емпатії у сфері медичної освіти, можна зазначити, що:

1. Тестові методики, які застосовують для діагностики емпатії в медицині, $\epsilon$, як правило, самооціночними.

2. Значна кількість методик діагностики емпатії часто не дає можливості адекватно порівнювати результати досліджень між собою.

3. В Україні відсутні спеціалізовані україномовні методики діагностики емпатії у студентів-медиків та працівників сфери охорони здоров'я.

4. Існує потреба в адаптації деяких іншомовних діагностичних методик для українських студентів-медиків та медичних працівників.

Таким чином, підбір оптимальних методик діагностики емпатії в медицині, їх адаптація, стандартизація та аналіз психометричних даних, а також створення нових україномовних діагностичних інструментів для оцінки емпатії $є$ перспективними напрямками дослідження даної проблеми у сфері медичної освіти та практичної охорони здоров’я.

5. The consultation and relational empathy (CARE) measure: development and preliminary validation and reliability of an empathy-based consultation process measure / S. W. Mercera, M. Maxwellb, D. Heaneyc [et al.] // Oxford Journals Medicine Family Practice. - Vol. 21.-P. 699-705.

6. Humanism at heart: preserving empathy in third-year medical students / S. Rosenthal, B. Howard, Y. R. Schlussel [et al.] // Acad. Med. -2011. - Vol. 86(3). - P. 350-358.

7. Ziolkowska-RudowiczE. Empathy-building of physicians. Part I-A review of applied methods / E. Ziolkowska-Rudowicz, A. Kladna // Pol. Merkur. Lekarski. - 2010. - Vol. 29(172). - 


\section{P. 277-281.}

8. Lin C. S. Differences between emergency patients and their doctors in the perception of physician empathy: implications for medical education / C. S. Lin, M. Y. Hsu, C. F. Chong // Educ. Health (Abingdon). -2008. - Vol. 21(2).P. 144 .

9. The Jefferson Scale of Physician Empathy : A preliminary psychometric study and group comparisons in Korean physicians / D. H. Suh, J. S. Hong, D. H. Lee [et al.] // Med.Teach.-2012.-34(6). - P. 464-468.

10. Pedersen R. Empirical research on empathy in medicineA critical review // Patient Educ. Couns. -2009. - Vol. 76(3). P. 307-322.

11. Hemmerdinger J. M. A systematic review of tests of empathy in medicine / J. M. Hemmerdinger, S. D. Stoddart, R. J. Lilford// BMC Med. Educ. -2007. - № 25(7). - P. 24.
12. Empathy in medical students as related to academic performance, clinical competence and gender / M. Hojat, J. S. Gonnella, S. Mangione [et al.] // Med. Educ. - 2002. - № 36(6). - P. 522-527.

13. DiLalla L. F. Effect of gender, age, and relevant course work on attitudes toward empathy, patient spirituality, and physician wellness / L. F. DiLalla, S. K. Hull, J. K. Dorsey // Teach Learn Med. - 2004. - № 16. - P. 165-170.

14. The Four Habits Coding Scheme: Validation of an instrument to assess clinicians' communication behavior / E. Krurpat, R. Francel, T. Stein [et al.] // Patient Education \& Counseling. - 2006. - № 62. - P. 38-45.

15. Evans B. J. Measuring medical students' empathy skills / B. J. Evans, R. O. Stanley, G. D. Burrows // Br . J. Med. Psychol.-1993.-№ 66.-P. 121-133. 